\title{
Н. А. Алексашенко
}

\section{ТРАНСПОРТИРОВКА ДОБЫЧИ ДРЕВНИМИ ЭСКИМОСАМИ ЭКВЕНА*}

doi: $10.30759 / 1728-9718-2020-2(67)-45-51$

УДК 902(571.651)

ББК63.4(2)

Статья посвящена реконструкции способов транспортировки морских животных, основанной на трасологическом изучении крюков и карабинов из Эквенского могильника (коллекции МАЭ РАН). Берингов пролив, на побережье которого расположен могильник, богат морскими животными. Их промысел был главным занятием древних эскимосов. В результате раскопок могильника найдено большое количество наконечников поворотного гарпуна, без которого была невозможна охота среди плавучих льдов. На основе их изучения С. А. Арутюнов и Д. А. Сергеев сделали вывод, что наконечники разных форм и размеров использовались для добычи кита, моржа или нерпы. Транспортировка убитых животных была важной частью промысла. В погребениях Эквенского могильника найдены крюки и карабины, служившие, по мнению исследователей, для этих целей. Мы попытались проверить это предположение применением микроанализа. Удалось выявить связь конструктивных особенностей со способами использования крюков и карабинов. Соединение крюка или карабина с животным производилось с помощью системы ремешков, следы от крепления и трения которых четко фиксируются под микроскопом. Через более крупные отверстия протягивался ремень от охотника (охотников). Следы изнашивания подтверждают интенсивную, длительную и многократную эксплуатацию крюков и карабинов. Самые крупные крюки могли служить для транспортировки кита по воде. Небольшие карабины использовались только для мелких зверей или для перемещения кусков мяса к месту хранения. Малочисленность крюков и карабинов в коллекции, возможно, объясняется широким применением ремней и линя в буксировке животных, о чем свидетельствуют этнографические факты.

Ключевые слова: Берингов пролив, Эквенский могильник, древние эскимосы, морская охота, крюки и карабины, трасологический анализ, транспортировка добычи

Целью нашего исследования является реконструкция способов транспортировки добычи древними эскимосами, основанная на микроанализе крюков и карабинов из Эквенского могильника, этнографических свидетельствах и данных экологии. В статье изложены результаты изучения предметов из раскопок Эквенского могильника 1960-х гг., хранящихся в Музее антропологии и этнографии имени Петра Великого (Кунсткамера) РАН. ${ }^{1}$

Эквенский могильник расположен на побережье Берингова пролива - одном из самых богатых биомассой регионов, особенно весной и осенью, во время миграций животных. ${ }^{2}$

\footnotetext{
${ }^{1}$ См.: Арутюнов С. А., Сергеев Д. А. Проблемы этнической истории Берингоморья (Эквенский могильник). М., 1975.

${ }_{2}$ См.: Основы морского зверобойного промысла: науч.-метод. пособ. / Богословская Л. И. [и др.]. М., 2007. С. 20, 21.

Алексашенко Наталья Анатольевна - к.и.н., с.н.с. Музей антропологии и этнографии им. Петра Великого (Кунсткамера) РАН (г. Санкт-Петербург) E-mail: sas-natalya@yandex.ru

* Выражаем искреннюю благодарность первым исследователям Эквенского могильника С.А.Арутюнову, Д. А.Сергееву, М. Г. Левину, их последователям М. М. Бронштейну и К. А. Днепровскому, нашему информатору Р.А. Емельянову, а также сотрудникам Кунсткамеры А. Ю. Сайфиевой, С. Н. Гиренко и Л. М. Дмитренко за помощь и поддержку.
}

Здесь существовали древнеэскимосские культуры морских охотников: древнеберингоморская (ДБК) и оквик - III/IV-VIII/IX вв., бирнирк IX-XI вв., пунук - XI-XIII вв. ${ }^{3}$ В Эквенском могильнике обнаружены предметы, свидетельствующие об охоте на сухопутных зверей, птиц, рыбной ловле, сборе растений. И все же больше всего было орудий морского промысла, главным из которых был поворотный гарпун. В Эквенском могильнике в 1960-е гг. в 93 из 189 раскопанных погребений найдено 409 наконечников гарпуна. ${ }^{4}$ С. А. Арутюнов и Д. А. Сергеев разработали их типологию и представили схему развития морского промысла на протяжении I тыс. н. э.: от добычи моржа, ластоногих и иногда кита к охоте на него как основной системе жизнеобеспечения населения побережья. ${ }^{5}$ Изотопный анализ показал, что в рационе древних эскимосов преобладали морские животные. ${ }^{6}$

\footnotetext{
3 См.: Днепровский К. А., Дэвлет Е. Г. К вопросу о конструктивных особенностях жилищ древних эскимосов по материалам археологии, этнографии и изобразительным источникам // Проблемы истории, филологии, культуры. 2017. № 3. С. 210.

${ }^{4}$ См.: Арутюнов С. А., Сергеев Д. А. Указ. соч. С. 75.

${ }_{5}$ См.: Там же. Гл. 3; Они же. О чем рассказывают гарпунные наконечники // Советская этнография. 1980. № 5. С. 136-145. ${ }^{6}$ См.: Козловская М. В. Образ жизни и пищевая стратегия древнеэскимосского населения // Северный археологический конгресс: докл. Екатеринбург, 2002. С. 166-168.
} 
Таблица 1

ХАРАКТЕРИСТИКА КРЮКОВ ИЗ ЭКВЕНСКОГО МОГИЛЬНИКА

\begin{tabular}{|c|c|c|c|c|c|}
\hline $\begin{array}{c}\text { Коллекционный } \\
\text { номер }\end{array}$ & $\begin{array}{c}\text { Номер } \\
\text { погребения }\end{array}$ & $\begin{array}{c}\text { Пол } \\
\text { погребенного }\end{array}$ & $\begin{array}{c}\text { Количество } \\
\text { предметов } \\
\text { вогребении }\end{array}$ & Размеры, см & Культура \\
\hline $6479-263$ & 10, парное с 11 & $\begin{array}{c}\text { мужской } \\
\text { и мужской }\end{array}$ & 58 & $12 \times 4,2 \times 3,7$ & ДБК \\
\hline $6551-1105$ & $\begin{array}{c}100, \text { парное с } \\
99\end{array}$ & $\begin{array}{c}\text { мужской } \\
\text { и женский }\end{array}$ & 154 & $14,8 \times 5,4 \times 3,4$ & $\begin{array}{c}\text { Ранний } \\
\text { пунук }\end{array}$ \\
\hline $6587-864$ & 143 & $\begin{array}{c}3 \text { костяка, } \\
\text { не указан }\end{array}$ & 96 & $9,6 \times 4,4 \times 3,0$ & $\begin{array}{c}\text { Ранний } \\
\text { пунук? }\end{array}$ \\
\hline $6588-17$ & 154 & женский & 171 & $10,2 \times 3,8 \times 2,7$ & ДБК \\
\hline $6588-834$ & $\begin{array}{c}183, \text { тройное } \\
\text { с 184-185 }\end{array}$ & не указан & 185 & $11 \times 3,25 \times 1,8$ & $\begin{array}{c}\text { Ранний } \\
\text { пунук }\end{array}$ \\
\hline
\end{tabular}

Важной задачей зверобоя была доставка убитого зверя к берегу. С. А. Арутюнов и Д. А. Сергеев обратили внимание на карабины и крюки и с помощью местных охотников реконструировали способы их использования в качестве транспортировочных приспособлений. ${ }^{7}$ В ходе работ экспедиции Государственного музея Востока (ГМВ) на Эквенских памятниках также обнаружены подобные предметы. ${ }^{8}$ Пока остается неясным, насколько большие нагрузки они могли выдерживать, остались ли следы такого воздействия, можно ли по их локализации определить конкретные способы использования? Было ли оно многократным? Требует объяснения малочисленность таких артефактов. Какой погребальный инвентарь найден вместе с ними? При рассмотрении этих вопросов мы опирались на результаты трасологического анализа, интерпретируя их с привлечением археологической типологии, планиграфии, экологии и этнографии.

Всего в коллекции обнаружены 10 предметов, имеющих форму крюка. Пять из них небольшие и тонкие. Они не могли выдержать сильного натяжения и давления и использовались, вероятно, в домашнем быту. Остальные крюки были более мощными (табл. 1). Все они сделаны из моржового клыка. Крюки и карабины изготовлены приемами пиления, резания, строгания, шлифования. Отверстия просверлены или прорезаны. Иногда в них заметны ступенчатые следы от скобления при расширении отверстия. Прием сверления ча-

\footnotetext{
7 См.: Арутюнов С. А., Сергеев Д. А. Древние культуры азиатских эскимосов (Уэленский могильник). М., 1969. С. 144, 145, рис. 72, 73, 96, 1, 4-6, 8; Они же. Проблемы этнической истории Берингоморья. С. 153.

${ }_{8}^{8}$ Мир арктических зверобоев. Шаги в непознанное. Каталог выставки. М.; Анадырь, 2007. С. 71, 128, 129. № в каталоге: 209, 210, 212.
}

сто использовался на первом этапе изготовления зубца крюка, а затем работа завершалась ножом. В оформлении всех предметов использовался прием гравировки. На крюках и карабинах присутствуют зооморфные и (или) антропоморфные изображения ${ }^{9}$ и орнамент (см. цв. вклейку, рис. 1, 2). Четыре экземпляра являются полиэйконичными: образы животных и человека переходят один в другой.

Крюки. 6479-263. Крюк-карабин с антропоморфным изображением представляет собой пластину толщиной 1 см в форме высокой трапеции с поперечной площадкой, расположенной почти под прямым углом (рис. 1, 1). В продольном разрезе предмет имеет Г-образную форму. Верхний торец выпуклый, в 1,5 см от него на боковых сторонах вырезаны уступчики по 0,4 cм. Такие же уступчики сделаны в нижней части на расстоянии 3,5 см от нижнего торца. В 1 см от верхнего торца просверлено сквозное отверстие диаметром 1 см. Оно расширено фаской. Также сквозное отверстие диаметром о,9 см просверлено сбоку в месте изгиба при переходе к горизонтальной площадке, в о,60,7 см от краев. Такое расположение отверстий при соответствующей толщине пластины позволяет крюку выдерживать большие нагрузки.

Вся поверхность предмета заглажена и заполирована. У крупного отверстия сглажена и скруглена кромка, на ней хорошо заметны сильный блеск и линейные следы (поперечные, диагональные и параллельные кромке). Наибольшая сработанность прослеживается в верхних двух третях периметра отверстия, но и его нижняя часть несет на себе следы

\footnotetext{
9 Рассмотрение сюжетов изображений и подробного описания техники их выполнения не входит в задачи нашего исследования и дано кратко.
} 
трения кожаного ремешка. Поперечные, продольные и диагональные линейные следы в виде бороздок и сопутствующий им блеск заметны на плоскостях выше отверстия и на верхнем торце. В сквозном отверстии в нижней части предмета также заметны диагональные, иногда перекрещивающиеся линии (бороздки) - следы натяжения и движения кожаного ремня. Наружные края отверстия скруглены, а следы заходят на боковые стороны.

6587-864. Крюк представляет собой массивную (толщиной 1,5 см) пластину неправильной пятиугольной формы с отверстием в верхней части $(2 \times 1,5$ см) и зубцом крюка в нижней (рис. 1, 2). Зубец длиной 4 см, шириной $2,7 \mathrm{~cm}$, толщиной $1,2 \mathrm{~cm}$ отклонен от пластины на 1,4 см в верхней части и на $0,7 \mathrm{~cm}$ в нижней. Расстояние от отверстия до верхнего края пластины $-1,8$ см, что в сочетании с массивностью крюка допускает возможность больших нагрузок на него. Крюк сильно сработан: верхний слой на зубце стерт. Лицевая, выпуклая сторона предмета заглажена, на ней многочисленные разнонаправленные царапины. Края отверстия сильно разношены, деформированы, на них фиксируются поперечные царапины с мягкими границами, блеск. Особенно хорошо они заметны на верхнем крае отверстия и на обеих сторонах прилегающих к нему участков. Такие следы образуются при сильном натяжении и трении под нагрузкой кожаного ремня. В канавке крюка наблюдаются аналогичные следы, заходящие вниз на боковые стороны. Подобный крюк с зооморфным (?) изображением, но с круглым отверстием (ртом) найден в погребении № 283, раскопанном экспедицией ГМВ. ${ }^{10}$

6561-1105. Крупный предмет с антропоморфным и зооморфными изображениями имеет заостренный крюк-зубец и три сквозных отверстия (рис. 1, 3). Зубец вытянутый треугольный, длиной 5 см (по внутреннему расстоянию от острия до основания - выемки-канавки), по всей длине отстоит от основной части предмета на расстоянии о,9 см. На расстоянии $2,5 \mathrm{~cm}$ от верхнего торца сделано отверстие овальной формы высотой 3 см, шириной 1,4 см. В этой же плоскости прорезаны два узких отверстия прямоугольной формы, размером 1,2 × 0,35 cм каждый. Поверхность крюка заглажена, но на ней есть выкрошенные участки. На краях отверстия и прилегающих участках заметны

10 См.: Мир арктических зверобоев. С. 129. № в каталоге: 212. сильный блеск и следы разной направленности в виде бороздок. Они образовались от трения кожаного ремня, который был подвижен в отверстии. Рабочий конец крюка также сильно изношен. Наиболее заметны следы в основании прорези зубца. Здесь следы распространяются и на боковые стороны, показывая направление движения. Износ свидетельствует о многократной большой нагрузке.

6588-17. Крюк с антропоморфным и зооморфными полиэйконичными изображениями ${ }^{11}$ найден в погребении с уникальной деревянной маской. Это массивный предмет, в 1,2 см от одного конца которого вырезано треугольное отверстие, деформированное в ходе использования (рис. 1, 4). Высота отверстия -2 см, а максимальная ширина 1,5 см. Длина крюка по внутреннему краю, от острого конца до канавки-выемки - 4,8 cм. По всей длине зубец отклонен от основной части крюка на 0,9 см. Несмотря на плохую сохранность и проведенную реставрацию, деформация и поперечные линейные следы заметны при небольшом увеличении.

6588-834. Предмет изображает морское животное, хвост которого загнут кверху, образуя круглый в сечении крюк (рис. 1, 5). Расстояние между загнутым крюком и основой составляет о,8 см. В о,4 см от верхнего ровного края просверлено отверстие диаметром 0,65 cм. В другой плоскости на крюке есть еще одно изображение животного. Микроанализ предмета показал интенсивную изношенность внутри в изгибе и по обеим сторонам вниз от него. Она наблюдается в виде выкрошенных участков верхнего слоя клыка, царапин, перекрывающих друг друга в разных направлениях. Отверстие и участки выше него деформированы и также имеют линейные следы вертикальной (вдоль длинной оси предмета) направленности. Маленькое расстояние до верхнего торца не могло обеспечить прочность в работе. Изучение верхнего торца показало, что он был ровно срезан и в нем был выбран паз, вероятно, для резца. Таким образом, мы зафиксировали вторичное назначение предмета, который первоначально использовался как крюк.

Карабины. 6479-383. Карабин имеет сложную форму (рис. 2,1 ). Верхняя часть - толстая пластина пятиугольной формы. Под ней в разных плоскостях вырезаны изображения

\footnotetext{
${ }^{11}$ См.: Арутюнов С. А., Сергеев Д. А. Проблемы этнической
} истории Берингоморья... С. 180. Рис. 56, 1. 
Таблица 2

ХАРАКТЕРИСТИКА КАРАБИНОВ ИЗ ЭКВЕНСКОГО МОГИЛЬНИКА

\begin{tabular}{|c|c|c|c|c|c|}
\hline $\begin{array}{c}\text { Коллекционный } \\
\text { номер }\end{array}$ & $\begin{array}{c}\text { Номер } \\
\text { погребения }\end{array}$ & $\begin{array}{c}\text { Пол } \\
\text { погребенного }\end{array}$ & $\begin{array}{c}\text { Количество } \\
\text { предметов } \\
\text { в погребении }\end{array}$ & Размеры, $c \mathcal{M}$ & Культура \\
\hline $6479-383$ & 11, парное с 10 & мужской & 106 & $8,5 \times 4,3 \times 2,0$ & ДБК \\
\hline $6479-384$ & 11, парное с 10 & мужской & 106 & $5,8 \times 3,2 \times 1,9$ & ДБК \\
\hline $6479-386$ & 11, парное с 10 & мужской & 106 & $4,5 \times 2,4 \times 2,0$ & ДБК \\
\hline $6587-622$ & $\begin{array}{c}\text { 139: } 3 \text { взрослых } \\
\text { и } 1 \text { младенец }\end{array}$ & не указан & 110 & $9,1 \times 4,9 \times 2,0$ & ДБК? \\
\hline 6588-37 & 154 & женский & 171 & $9,2 \times 3,1 \times 2,0$ & ДБК \\
\hline $6588-284$ & $155^{-156}$ & не указан & 129 & $4,8 \times 2,0 \times 2,0$ & $\begin{array}{c}\text { Бирнирк - } \\
\text { ранний пунук? }\end{array}$ \\
\hline 6588-1164 & 189 & не указан & 53 & $4 \times 1,9 \times 2,2$ & \multirow{3}{*}{$\begin{array}{c}\text { Бирнирк - } \\
\text { ранний пунук? }\end{array}$} \\
\hline 6588-1214 & 189 & не указан & 53 & $5,6 \times 2,5 \times 2,5$ & \\
\hline $6588-1224$ & $\begin{array}{c}\text { подъемный } \\
\text { материал }\end{array}$ & & & $6,2 \times 2,1 \times 1,8$ & \\
\hline
\end{tabular}

медвежьих голов, образующие У-образную конструкцию. Нижняя часть в плане трапециевидная, в продольном сечении овальная. В ней сбоку просверлено сквозное отверстие диаметром 0,7-0,8 cм, расширенное фаской до 1,3 см. В 1 см от верхнего ровного торца прорезано отверстие треугольной формы высотой 1,5 см, шириной 1,45 см. Отверстия сильно разношены. Расположение и направление линейных следов как в самих отверстиях, так и на обеих торцах свидетельствуют, что ремни не просто были пропущены в отверстия, но и завязаны. Крепление не было совсем жестким, и от трения ремней образовались многочисленные бороздки и царапины со сглаженными границами.

6587-622. Зооморфный карабин выполнен в форме плывущего зверя с обозначенной головой и выделенными «ластами» (рис. 2, 2). На оборотной стороне часть моржового клыка выбрана так, что получилась выемка трапециевидной формы. На расстоянии 1,3 см от слегка скругленного торца вырезано треугольное отверстие высотой 1,5 см и максимальной шириной 1,2 см. В нем и прилегающем участке от отверстия до торца следы от трения кожаного ремня хорошо заметны без микроскопа. Сквозь «ласт» вдоль длинной оси просверлено по одному отверстию диаметром о,6 см. В них и на перемычке между ними зафиксированы следы трения ремешка. Ремешок был перекинут из одного отверстия в другое, а концы выведены в сторону «головы животного».

6479-384. Карабин представляет собой массивную пластину прямоугольной формы (рис. 2, 3). В нижней части по бокам срезаны небольшие выемки, а края торца скруглены, что придает предмету форму звериной морды. Одна сторона выпуклая. На другой стороне выбрано (вырезано) удлиненное трапециевидное углубление (аналогичное углублению на карабине 6587-622). В верхней половине предмета прорезано треугольное сквозное отверстие высотой 1,35 см, шириной 1,65 см, которое сильно изношено, особенно в верхней части. Сильный жирный блеск и линейные следы от трения кожаного ремня от отверстия распространяются вверх, к торцу. В центральной части с выпуклой стороны (под наклоном к ней) просверлены два круглых сквозных отверстия диаметром о,7 см. Их края выкрошены, линейные следы имеются на отдельных участках. Через всю утолщенную часть нижнего торца просверлены два отверстия диаметром 0,7 см, края которых выкрошены. В них поперечнодиагональные тонкие жесткие царапины.

6588-37. Карабин с двойным зооморфным изображением (белого медведя, горного барана) найден в одном погребении с крупным крюком (рис. 2, 4). В 1 см от одного конца круглое отверстие диаметром 1,2 см. Два отверстия диаметром 0,5-0,6 см просверлены вдоль длинной оси через выступ. Следы изнашивания, как и на других карабинах, расположены преимущественно на краях отверстий и прилегающих к ним участках.

6479-386. Небольшой карабин имеет неправильную цилиндрическую форму с перехватом в центре (рис. 2, 5). Обтекаемая форма и несколько резных линий придают ему 
зооморфный облик. С торцов, поперек длинной оси артефакта встречным сверлением сделаны два отверстия диаметром о,6 cм, от которых к узким краям прорезаны такой же ширины небольшие канавки - направляющие для ремешков. В них, а также в отверстиях зафиксированы отчетливые следы трения ремешков. На торцах они не прослеживаются. Края отверстий разношены и скруглены.

6588-284. Карабин с изображениями трех звериных голов (рис. 2, 6) имеет цилиндрическую форму. С одного конца просверлено отверстие диаметром 0,6 cм, которое соединяется с двумя отверстиями такого же диаметра, просверленными с другого торца. В ходе эксплуатации перемычка между двумя отверстиями была сломана, через предмет прошла трещина и появились многочисленные царапины. Края отверстий выкрошены.

6588-1164. Небольшой зооморфный карабин имеет два сверленых отверстия диаметром o,65 см, расположенных поперек к продольной оси предмета. Вся поверхность карабина покрыта мелкими сколами, царапинами, сохранившиеся участки заглажены. Края отверстий и промежуток между ними выкрошены и покрыты микроцарапинами.

6588-1214. Короткий, круглый в поперечном сечении карабин имеет зооморфный облик. Две пары встречных отверстий диаметром о,6 см нанесены в плоскостях, перпендикулярных друг другу: поперек «морды» и вдоль «живота». Участки возле отверстий выкрошены. Остальная поверхность заглажена.

6588-1224. У зооморфного карабина без сквозных отверстий, но с продольной канавкой не сохранился верхний слой. Он покрыт трещинами, края канавки и голов зверей сколоты. По общему облику и размерам он похож на два предыдущие, но непригоден для трасологического анализа.

Инвентарь погребений с крюками и карабинами. Все погребения содержали предметы промыслового, бытового и сакрального назначения: лук и его детали, наконечники стрел, бола, шатины, полозья санок из моржового клыка, инструменты (резцы, тесла, сверла), игольники, иглы, фрагменты керамики, ведерки из китового уса, орнаментированные корытца, модели каяков, фигурки китов, медведей, птиц, моржей. Во всех захоронениях присутствуют детали поворотного гарпуна: наконечники, колки, головки древков, крылатые предметы, в погребении № 100 - деревянная копьеметалка. ${ }^{22}$ В снаряжение промысловика входили: пика, копье, поплавок (сохранились затычки, мундштуки), ледовые пешни, затычки для ран, багры, большой нож для очистки шуги. Согласно типологии С. А. Арутюнова и Д. А. Сергеева, ${ }^{13}$ наконечники гарпуна в погребении № 10-11 служили для охоты: $2-$ на кита, 5 - на нерпу, остальные $9-$ на моржа и, возможно, крупных тюленей. В погребении № 100 из 7 наконечников гарпуна 3 , длиной 20-21 cм, предназначались для охоты на кита, 1 - на нерпу, 3 - на моржа. Среди 14 экземпляров из погребения № 139 есть наконечники для промысла моржа, тюленей, в том числе единично нерпы. В погребениях № 143 и 154 по 9 наконечников, среди которых по одному могли использоваться в охоте на кита. Остальные предназначались в основном для добычи моржа и нерпы, меньше - других ластоногих. Из парного погребения № 155-156 происходят 10 наконечников гарпуна, которые по размерам могут принадлежать гарпуну на кита 2 экземпляра, на нерпу - 2, на моржа -3 , остальные как на моржа, так и на тюленей. В тройном погребении № 183 найдено 19 наконечников поворотного гарпуна: 1 - на кита, 5 - на моржа, 4 - на нерпу, остальные - на моржа или тюленей. В погребении № 189 из 53 артефактов - 7 наконечников поворотного гарпуна: крупный (15 см длиной) мог использоваться для охоты на кита или моржа, два мелких - на нерпу, остальные на моржа и тюленей. Представленные в погребениях с крюками наконечники свидетельствуют о круглогодичной охоте на разных животных.

В Эквенском могильнике материалом для погребальных сооружений служили кости кита и моржа, в выстилке отдельных погребений встречается шкура медведя. В нескольких погребениях найдены клыки и когти медведя, нерпичьи лопатки, кости песца и зайца. Основным сырьем для изготовления орудий и бытовых предметов был моржовый клык. Реже использовались кости моржа, кита, нерпы, тюленя, оленя, китовый ус.

Кости взрослых особей и детенышей гренландского кита обнаружены в древних сооружениях на побережье всей Чукотки. ${ }^{14}$ Габариты животных определяли возможности и способы

\footnotetext{
${ }^{12}$ См.: Мифы и вещи: искусство древних эскимосов Эквена. Каталог выставки. МАЭ РАН. СПб., 2019. С. 22-23.

${ }^{13}$ См.: Арутюнов С. А., Сергеев Д. А. Проблемы этнической истории Берингоморья... С. 77, 78.

${ }^{14}$ См.: Богословская Л. И. [и др.]. Указ. соч. С. 139.
} 
их транспортировки. Длина среднего взрослого гренландского кита 16-18 м, вес - 30-50 т, трехмесячного детеныша $-6-7$ м при весе 650 кг. Длина серого кита $-14 \mathrm{M}$, вес $-20-35$ т. Морж весит 800-1500 кг при длине тела 2,84,5 м. Тюлени: лахтак имеет длину 2,25 м, вес220-280 кг; ${ }^{15}$ полосатый тюлень: 1,55-1,65 м, 55 кг; кольчатая нерпа: 1-1,5 м, 30-80 кг.

Этнографические свидетельства транспортировки добычи. Во время работы экспедиции С. А. Арутюнов и Д. А. Сергеев выяснили у местных жителей, как могли использоваться крюки и карабины. ${ }^{16}$ Современные чукчи и эскимосы на охоту на припае на мелких ластоногих, прежде всего нерпу, обязательно берут шест, один конец которого - ледовая пешня в виде металлического наконечника, второй конец - крюк, согнутый из металлического прута диаметром 0,6-0,8 см. ${ }^{17}$ Диаметр самого крюка - 3-4 см. У нерпы делают надрез в нижней челюсти, переворачивают ее и тащат по льду до санок. Для более крупных животных используется крюк диаметром $10 \mathrm{~cm}$ из прута диаметром 1 см. Подобный шест есть на фото охотника, сделанном Александром Форштейном в 1927-1929 гг. ${ }^{18}$

Убитую в воде нерпу охотник в лодке цепляет за морду крюком и буксирует добычу к кромке льда. Для более тяжелой добычи добавляют еще один крюк и вдвоем-втроем вытаскивают нерпу на лед. ${ }^{19}$

Для транспортировки кита требовалось 30-40 охотников (на веслах). Использовались ремни и 5-6 поплавков. ${ }^{20}$ Часто охотились на мелких китов, так как их легче было доставить к берегу. ${ }^{21}$ Иногда производилась частичная разделка в море или на ледовом припае ${ }^{22}$ с последующей буксировкой к мясным ямам крюками, называемыми тяговыми.

Туши забитых моржей привязывают снаружи к байдаре, используя дополнительно поплавки. Два поплавка держат моржа весом около тонны. О существовании специальных ремней для буксировки кита и моржа упоми-

\footnotetext{
15 Там же. С. 77.

${ }_{16}$ См.: Арутюнов С. А., Сергеев Д. А. Древние культуры азиатских эскимосов. С. 144, 145. Рис. 72.

17 Сведения получены от Р. А. Емельянова, 1969 г. р., сына чукотского морского зверобоя А. Д. Емельянова.

${ }^{18}$ См.: Крупник И. И., Михайлова Е. Е. Пейзажи, лица и истории: эскимосские фотографии Александра Форштейна (19271929 гг.) // Антропологический форум. 2006. Вып. 4. С. 203. Рис. 1. 19 См.: Богословская Л. И. [и др.]. Указ. соч. С. 296.

${ }_{20}$ См.: Арутюнов С. А., Крупник И. И., Членов М. А. «Китовая аллея». Древности островов пролива Сенявина. М., 1982. С. 133.

${ }_{21}$ См.: Крупник И. И. Арктическая этноэкология. М., 1989. С. 79.

22 Арутюнов С. А. [и др.]. «Китовая аллея»... С. 129, 130.
}

нал Д. А. Сергеев, описывая моржовый промысел. Особо прочный тонкий ремень вырезали из шкуры моржонка. ${ }^{23}$ По свидетельству Р.А. Емельянова, в море с помощью крюков буксируют моржа и кита. Задние ласты моржа соединяют и пропускают крюк, кита цепляют крюком за хвост (связывают две половинки хвоста ремнем и транспортируют). От кромки воды к месту разделки крупных животных (кита, моржа) перемещали методом переката, обмотав линем. Обычно в этом участвовали все охотники и жители поселка.

Обсуждение результатов. Мы обнаружили в коллекции Эквенского могильника и изучили под микроскопом 5 крюков и 9 карабинов. Крюки и карабины имеют форму, в которой угадывается облик одного или нескольких зверей и человека. Все крюки достаточно большие и массивные и способны выдержать большую нагрузку. Один из них сочетал в себе признаки крюка и карабина (рис. 1, 1). Крупный крюк из погребения № 100 имел дополнительные отверстия (рис. 1, 3). Среди карабинов три экземпляра также довольно крепкие и большие (рис. 2, 1, 2, 4), остальные были значительно мельче (рис. 2, 5, 6). Пока нами не выявлены в коллекции Эквена составные карабины, подобные тем, что нарисовал эскимос Унук. ${ }^{24}$ Карабины с большим отверстием и парой мелких использовались с двумя ремнями. Один из них, узкий (о,6-о,8 см), но прочный (из шкуры моржонка?), протягивался через парные отверстия: следы трения от ремешка заметны на перемычке между ними. Вторые концы, вероятно, привязывали через отверстие, прорезанное в челюсти животного, и закрепляли узлом. Через более крупное отверстие пропускался ремень шириной до 1,5-2 см, за который и тянули добычу. Мелкие карабинчики имели небольшие отверстия для тонких ремешков. Они могли использоваться для транспортировки небольших животных. Их сохранность хуже, чем у более крупных экземпляров.

Крюки имеют следы сильного и длительного воздействия - натяжения кожаных ремней, как в отверстиях, на прилегающих поверхностях, так и внутри изгиба зубца. Они использовались многократно. Наибольшую нагрузку выдерживали два крюка с большими отверстиями (рис. $1,3,4$ ). Они могли использоваться для транспортиров-

\footnotetext{
${ }^{23}$ См.: Сергеев Д. А. Моржовый промысел населения Берингоморья // КСИЭ. 1963. Вып. 38. С. 79.

${ }^{24}$ См.: Арутюнов С. А., Сергеев Д. А. Древние культуры азиат-
} ских эскимосов... Рис. 72. 
ки кита по воде способом, аналогичным описанному Р. А. Емельяновым. Немногочисленность крюков может объясняться наличием способов транспортировки без их применения, а только с помощью ремней. Крюки и карабины также выполняли важные сакральные функции, о которых мы можем судить по этнографическим и фольклорным источникам.

\section{Natalia A. Aleksashenko}

Candidate of Historical Sciences, Peter the Greate Museum of Anthropology and Ethnography (Kunstkamera) of the RAS (Russia, St. Petersburg)

E-mail: sas-natalya@yandex.ru

\section{TRANSPORTATION OF PREY BY THE ANCIENT EKVEN ESCIMO}

The article is devoted to the reconstruction of marine animals transportation methods, based on the use-wear analysis of hooks and carabines from the Ekven cemetery (MAE RAS collection). The Bering Strait, on the coast of which the cemetery is located, is rich in marine animals. Maritime hunting was the main occupation of the Ancient Eskimo. As a result of excavation of the burials, a large number of toggle harpoon heads were found, without which hunting was impossible among the floating ice. On the basis of their study S. A. Arutyunov and D. A. Sergeev concluded that the harpoon heads of different shapes and sizes were used for the hunting whales, walruses or seals. It was important to transport killed animal to the shore. According to the researchers, hooks and carbines from the Ekven cemetery were used for these purposes. We tried to test this hypothesis with the microanalysis. It was possible to identify the connection of design features with the ways of using hooks and carbines. The hook or carbine was connected to the animal by straps, the traces of fastening and friction of which are clearly recorded under the microscope. Through the larger holes a belt from the hunter (hunters) was stretched. Wear marks confirm the intensive, long-term and repeated use of hooks and carbines. The largest hooks could be used to transport a whale by water. Small carbines were used only for small animals or for removing pieces of meat to the storage area. Small numbers of hooks and carbines in the collection may be explained by the widespread use of belts and lines in towing animals, as evidenced by ethnographic facts.

Keywords: Bering Strait, Ekven cemetery, Ancient Eskimo, maritime hunting, drag hook, carbine, use-wear analysis, transportation (dragging) of killed maritime animals

\section{REFERENCES}

Arutyunov S. A., Krupnik I. I., Chlenov M. A. «Kitovaya alleya». Drevnosti ostrovov proliva Senyavina ["Whale Alley". Antiquities of the Senyavin Strait Islands]. Moscow: Nauka Publ., 1982. (in Russ.).

Arutyunov S. A., Sergeev D. A. [What harpoon tips tell]. Sovetskaya etnografiya [Soviet Ethnography], 1980, no. 5, pp. 136-145. (in Russ.).

Arutyunov S. A., Sergeev D. A. Drevnie kultury aziatskikh eskimosov (Uelenskiy mogilnik) [Ancient cultures of Asian Eskimo (the Uelen burial ground)]. Moscow: Nauka Publ., 1969. (in Russ.).

Arutyunov S. A., Sergeev D. A. Problemy etnicheskoy istorii Beringomorya (Ekvenskiy mogilnik) [Problems of the Bering Sea region ethnic history (the Ekven burial ground)]. Moscow: Nauka Publ., 1975. (in Russ.).

Bogoslovskaya L., Slugin I., Zagrebin I., Krupnik I. Osnovy morskogo zveroboynogo promysla. Nauchnometodicheskoe posobie [Basics of marine hunting. Scientific and methodological manual]. Moscow: Institut Naslediya Publ., 2007. (in Russ.).

Dneprovskiy K. A., Devlet E. G. [On the subject of structural features of dwellings of the ancient Escimo in consideration with archaeological materials, ethnography and artistic sources]. Problemy istorii, filologii, kul'tury [Problems of history, philology, culture], 2017, no. 3, pp. 210-251. (in Russ.).

Kozlovskaya M. V. [Way of life and the dietary strategy of the ancient Eskimo population]. Severnyy arkheologicheskiy kongress: doklady [Northern Archaeological Congress. Papers]. Ekaterinburg: Akademkniga Publ., 2002, pp. 150-172. (in Russ.).

Krupnik I. I. Arkticheskaya etnoekologiya [Arctic ethnoecology]. Moscow: Nauka Publ., 1989. (in Russ.).

Krupnik I. I., Mikhaylova E. E. [Landscapes, Faces, and Tales: Eskimo Photographs by Alexander Forstein (19271929)]. Antropologicheskiy forum [Forum for Anthropology and Culture], 2006, iss. 4, pp. 188-219. (in Russ.).

Mify i veshchi: iskusstvo drevnikh eskimosov Ekvena. Katalog vystavki [Myths and things: the art of the ancient Ekven Eskimo. Exhibition catalog]. Saint Petersburg: MAE RAN Publ., 2019. (in Russ.).

Mir arkticheskikh zveroboev. Shagiv nepoznannoe. Katalog vystavki [World of Arctic sea-hunters. Steps into the unknown. Exhibition catalog]. Moscow; Anadyr: Gosudarstvennyy muzey Vostoka Publ., 2007. (in Russ.). Sergeev D. A. [Walrus hunting of the Bering Sea region population] Kratkiye soobshcheniya Instituta arkheologii [Brief Reports of the Institute of Archaeology], 1963, iss. 38, pp. 77-81. (in Russ.). 


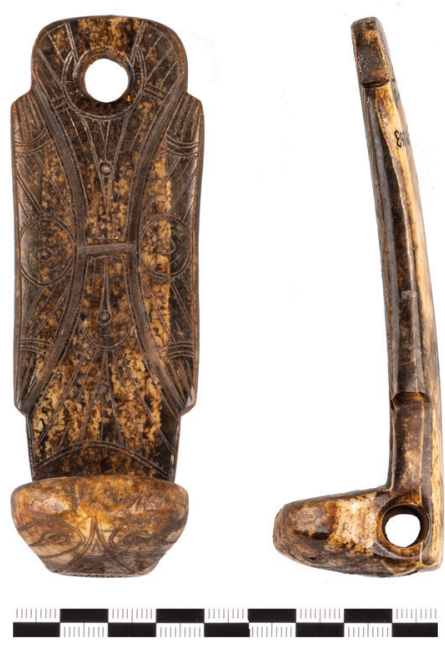

№ 6479-263
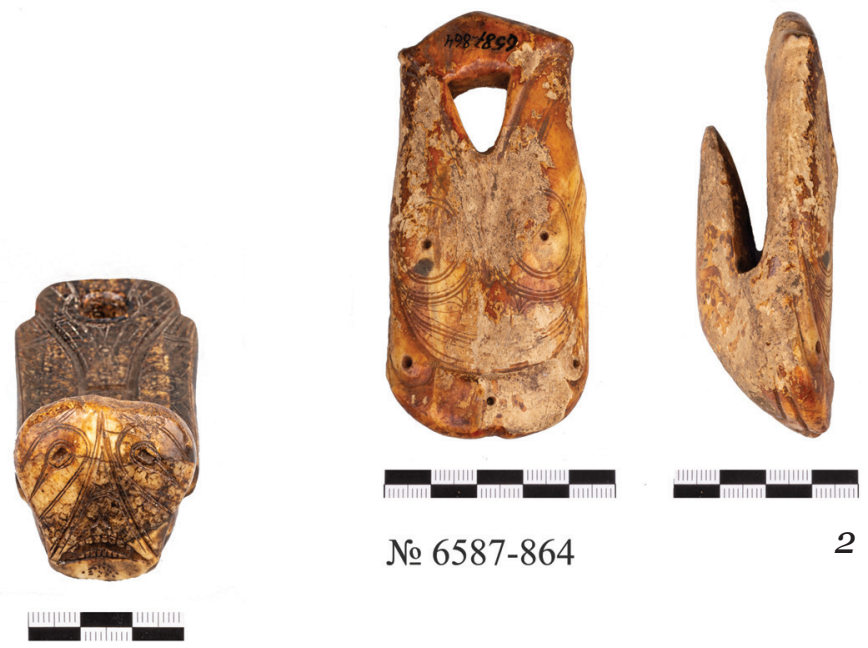

№ 6587-864
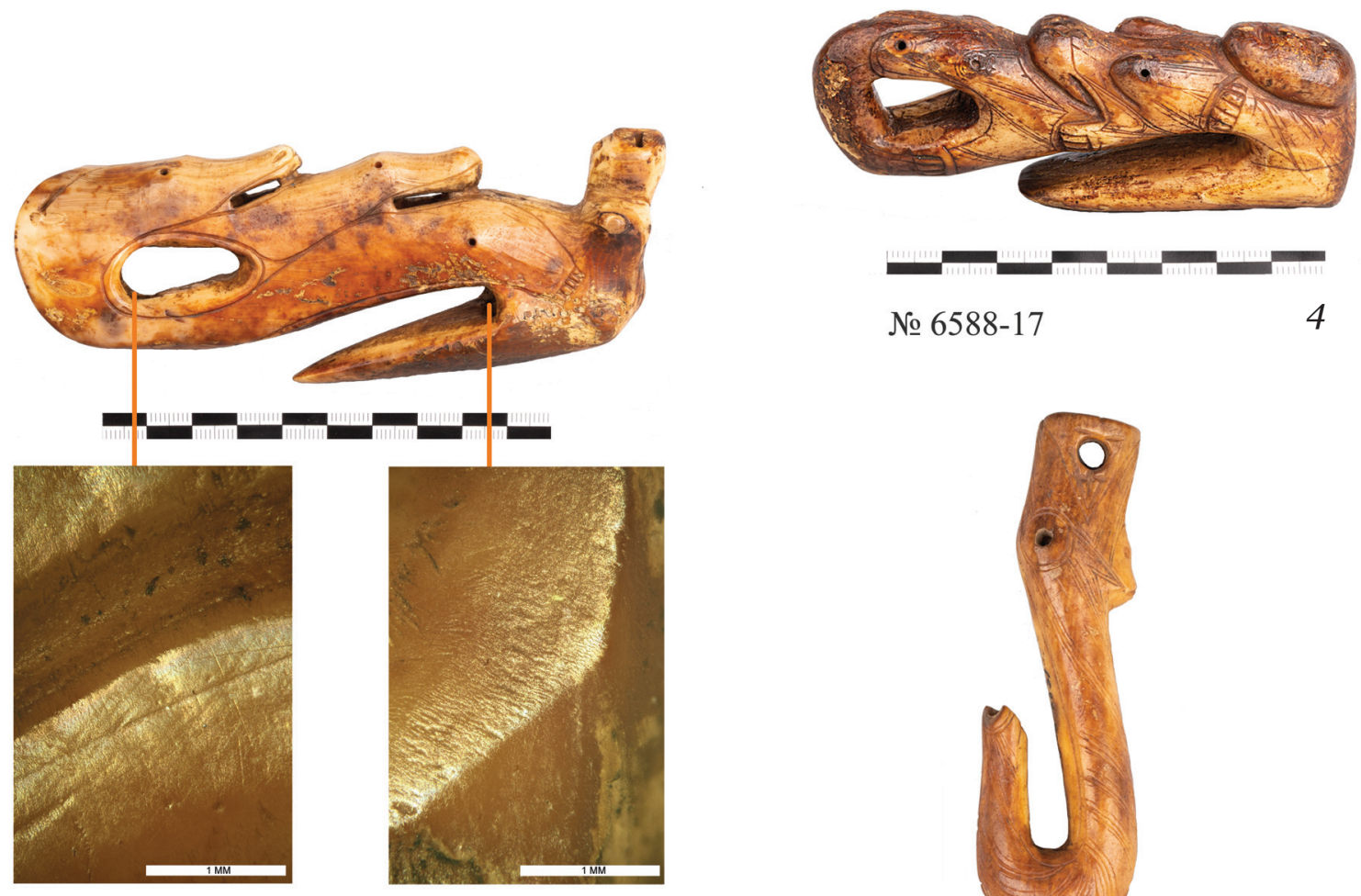

№ 6561-1105

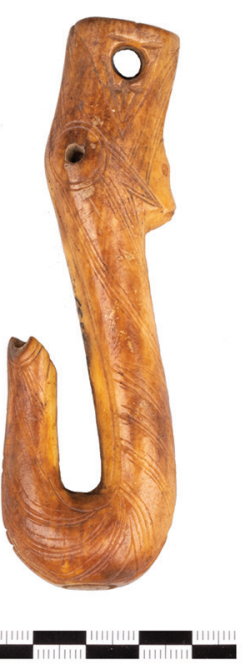

№ 6588-834 5

Рис. 1. Крюки из Эквенского могильника

1 - погребение № 10-11 (лицевая сторона и профиль);

2 - погребение № 143 (лицевая сторона и профиль);

3 - погребение № $10 о$ (общий вид и следы использования);

4- погребение № 154; 5 - погребение № 183 


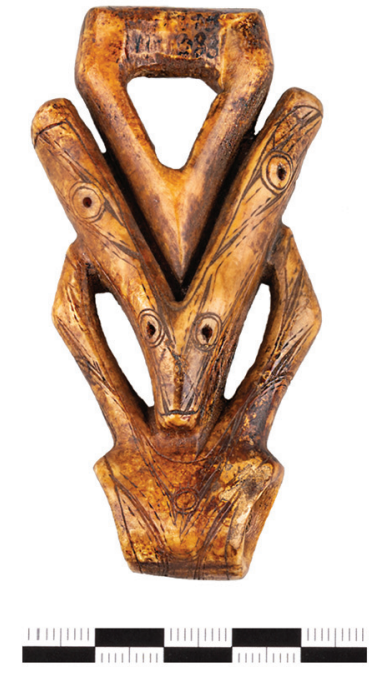

№ 6479-383
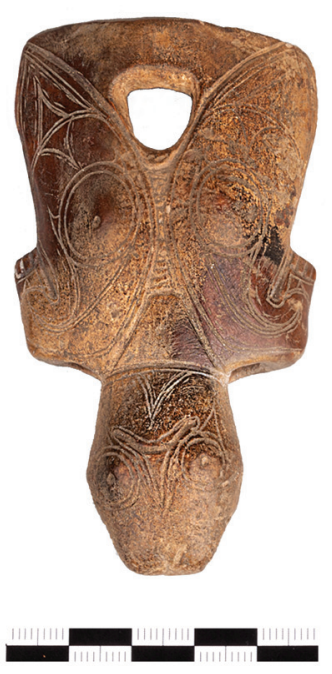

№ 6587-622
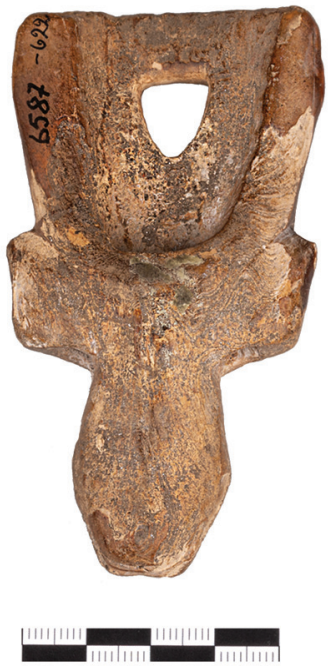

2

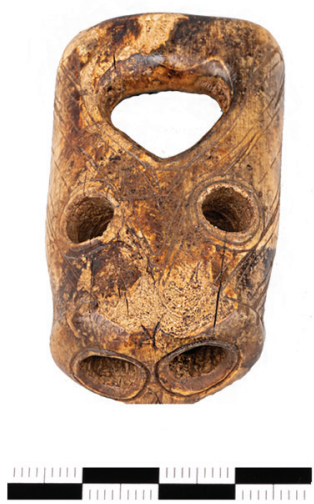

№ 6479-384
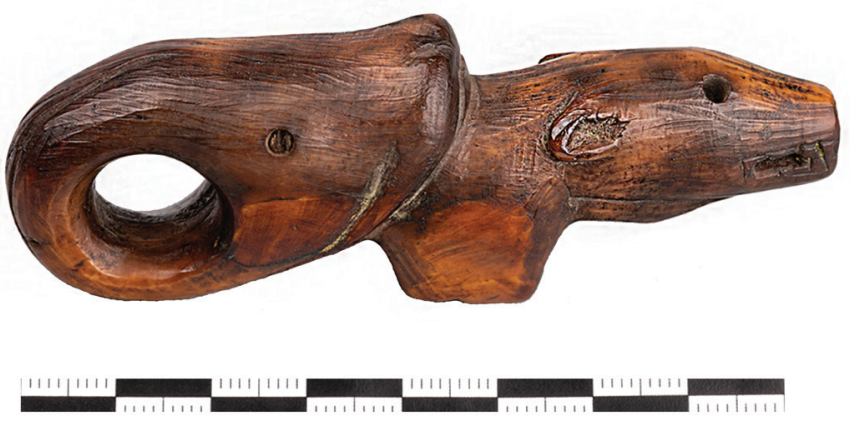

№ 6588-37
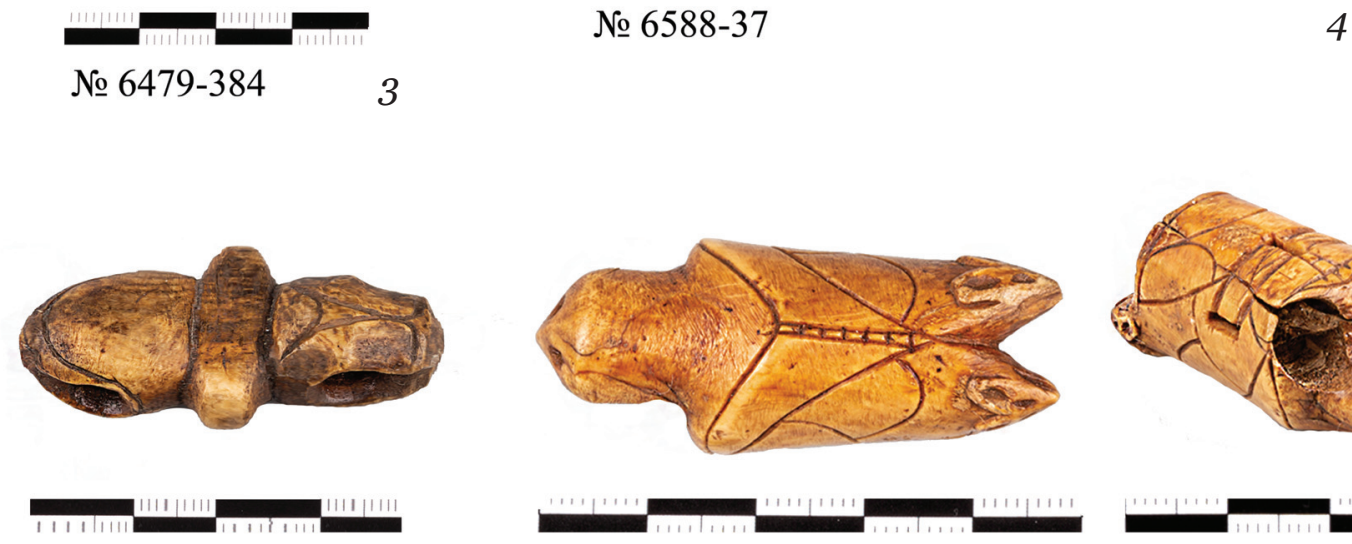

№ 6588-284

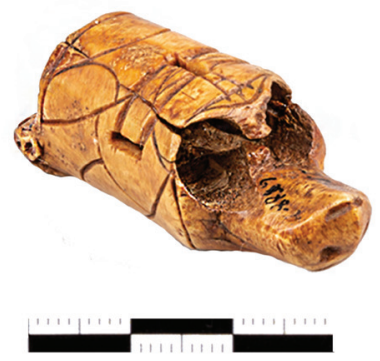

6

Рис. 2. Карабины из Эквенского могильника

1, 3, 5 - погребение № 10-11; 2 - погребение № 139 (лицевая и оборотная сторона); 4- погребение № 154; 6 - погребение № 155-156 (лицевая и оборотная сторона) 